\title{
The impact of rainfall and seasonal variability on the removal of bacteria by a point-of-use drinking water treatment intervention in Chennai, India
}

\author{
Morgan C. MacDonald ${ }^{\mathrm{a} *, 1}$, Luke Juran ${ }^{\mathrm{b}}$, Jincy Jose ${ }^{\mathrm{c}}$, Sekar Srinivasan ${ }^{\mathrm{c}, 2}$, \\ Syed I. Ali ${ }^{\mathrm{a}}$, Kristan J. Aronson ${ }^{\mathrm{d}}$ and Kevin Hall ${ }^{\mathrm{a}, 3}$ \\ ${ }^{a}$ School of Engineering, University of Guelph, Guelph, Canada; ${ }^{b}$ Department of Geography and \\ Virginia Water Resources Research Center, Virginia Tech, Blacksburg, VA, USA; ${ }^{c}$ Department of \\ Civil Engineering, Indian Institute of Technology Madras, Chennai, India; ${ }^{d}$ Department of Public \\ Health Sciences, Queen's University, Kingston, ON, Canada
}

(Received 18 December 2014; final version received 22 May 2015)

\begin{abstract}
Point-of-use water treatment has received widespread application in the developing world to help mitigate waterborne infectious disease. This study examines the efficacy of a combined filter and chemical disinfection technology in removing bacterial contaminants, and more specifically changes in its performance resulting from seasonal weather variability. During a 12-month field trial in Chennai, India, mean log-reductions were 1.51 for $E$. coli and 1.67 for total coliforms, and the highest concentration of indicator bacteria in treated water samples were found during the monsoon season. Analysis of variance revealed significant differences in the microbial load of indicator organisms (coliforms and E. coli) between seasons, storage time since treatment (TST), and samples with and without chlorine residuals. Findings indicate that the bacteriological quality of drinking water treated in the home is determined by a complex interaction of environmental and sociological conditions. Moreover, while the effect of disinfection was independent of season, the impact of storage TST on water quality was found to be seasonally dependent.
\end{abstract}

Keywords: bacteria; India; point-of-use; seasonal variability; water treatment

\section{Introduction}

An estimated 750,000 children die each year in the Global South as a result of diarrhoeal disease, an illness that is largely preventable with access to safe drinking water and adequate sanitation infrastructure (Kosek et al. 2003; Boschi-Pinto et al. 2008; Liu et al. 2012). To that end, goal four of the United Nations Millennium Development Goals aims to reduce the under- 5 child mortality rate by two-thirds by 2015 , and goal 7C aims to halve the proportion of the population without sustainable access to safe drinking water and basic sanitation (WHO 2002). Furthermore, the World Health Organization declared point-of-use (PoU) household water treatment and safe storage to be an effective method for achieving these goals (WHO 2011) for the 780 million

\footnotetext{
*Corresponding author. Email: m.macdonald@griffith.edu.au

${ }^{1}$ Current affiliation: Australian Rivers Institute, Griffith School of Environment, Griffith University, Nathan, 170 Kessels Road, QLD 4111, Australia, Sir Samuel Griffith Centre (N78) 4.11.

${ }^{2}$ Department of Management Studies, Indian Institute of Technology Madras, India.

${ }^{3}$ DVC Research, University of Newcastle, Australia.
} 
individuals who lack access to improved water sources, and the millions more consuming microbiologically unsafe water from improved water sources.

Epidemiological evidence suggests that diarrhegenic microbes are seasonally dependent and influenced by changes in the ambient environment (Sood et al. 2008; Jones et al. 2013). Carlton et al. (2013) posited that heavy rainfall associated with diarrhoeal incidence is the consequence of surface run-off that is high in bacterial loads. Sahoo et al. (2010), while studying antibiotic resistance in Orissa, India, determined a higher prevalence of diarrhoea during the rainy season. The presence and persistence of waterborne pathogens in surface waters is inextricably linked to environmental factors such as sunlight (Burkhardt et al. 2000), temperature (Sharan et al. 2010) and rainfall (Martin et al. 2010). A study of the tropical Rio Grande de Arecibo watershed in Puerto Rico found evidence of an increase in the concentration of thermotolerant coliforms $48 \mathrm{~h}$ after a heavy rainfall event (Santiago-Rodriguez et al. 2012). The same study reported a reduction in coliform concentrations following a moderate rainfall event, which the authors attributed to a possible dilution effect. In the Mekong Delta, Isobe et al. (2004) noted distinct seasonal differences in the concentrations of Coprostanol, a proven indicator of faecal pollution, with the lowest concentrations reported during the dry season. The collective significance of these studies demand that PoU water treatment technologies must be robust in their ability to treat water of varying microbiological and physicochemical properties if they are to be effective barriers against the transmission of waterborne pathogens.

There are very few articles that report the effect of seasonal change on PoU water treatment, and none that describe this relationship in detail. While studying the health impacts of biosand water filtration in the Dominican Republic, Stauber et al. (2009) found less reduction in diarrhoeal incidence in intervention households during the rainy season compared to the dry season, relative to controls. During the dry season, households relied more heavily on contaminated water sources such as surface water, wells, or intermittent piped supplies when higher quality rainwater was unavailable. Albert et al. (2010) describe the selection of household water source in rural Kenya as a complex process that is largely dependent on seasonal rainfall. In episodes of water abundance due to rainfall, households relied primarily on surface water sources identified to contain the highest concentrations of $E$. coli. However, the impact of seasonal variability on PoU water treatment effectiveness was not discussed. Moreover, the majority of intervention studies are too brief to accurately capture the temporal impact of seasonal variability on treatment efficacy, and failure to report at least 12 months of data collection can constrain or bias the reported effect (Blum and Feachem 1983; Clasen et al. 2007; Hunter 2009).

This study explores the seasonal fluctuations in the bacteriological removal effectiveness of a PoU water treatment system that combines dual-media bucket filtration with chemical disinfection and safe storage in Mylai Balaji Nagar (MBN), an underserviced community in Chennai, India. Given widespread application of PoU water treatment in developing countries, more research is required to examine the impact of seasonal variability on treatment effectiveness. Greater understanding of the potential treatment variability of PoU technologies could be used to inform the selection of treatment technology according to physical geography and climate, as well as advise on the potential vulnerabilities of treatment effectiveness caused by seasonal weather variability. To these ends, the objectives of this work are to: (a) explore seasonal bacterial loading and physicochemical changes to the surface water source; (b) investigate seasonal differences in the effectiveness of a PoU technology to remove bacteriological contaminants 
(the Safe Water Technology or SWT); and (c) examine the impact of storage time on bacteriological concentrations as a function of season. To satisfy these objectives, the SWT-consisting of a dual-media bucket filter, a safe water storage vessel and sodium dichloroisocyanurate $(\mathrm{NaDCC})$ tablets for disinfection-was examined for its ability to remove $E$. coli and total coliform bacteria in participants' homes. Temperature and rainfall data were also analysed for their effects on the bacterial densities of both treated and untreated water samples, and the overall efficacy of the SWT.

\section{Materials and methods}

\section{The Safe Water Technology}

The SWT was designed using a participatory framework and employed indigenous knowledge to guide the development processes. As detailed in MacDonald et al. (2013), 12 months of baseline water quality data were used to advise researchers and participants in the selection of an appropriate treatment system. A multi-barrier PoU technology employing filtration and chemical disinfection was determined to be most appropriate for reducing problematic contaminants, including organic matter and microbes, and it was also identified as the most culturally and socio-economically sensitive technology. The dual-media, gravity-fed bucket filter contained $15 \mathrm{~cm}$ of charcoal, on top of which was $15 \mathrm{~cm}$ of sand (size $0.2-0.4 \mathrm{~mm}$ ), both supported by a $7 \mathrm{~cm}$ bed of gravel. Figure 1 presents a photograph of the filter being used inside a participant's
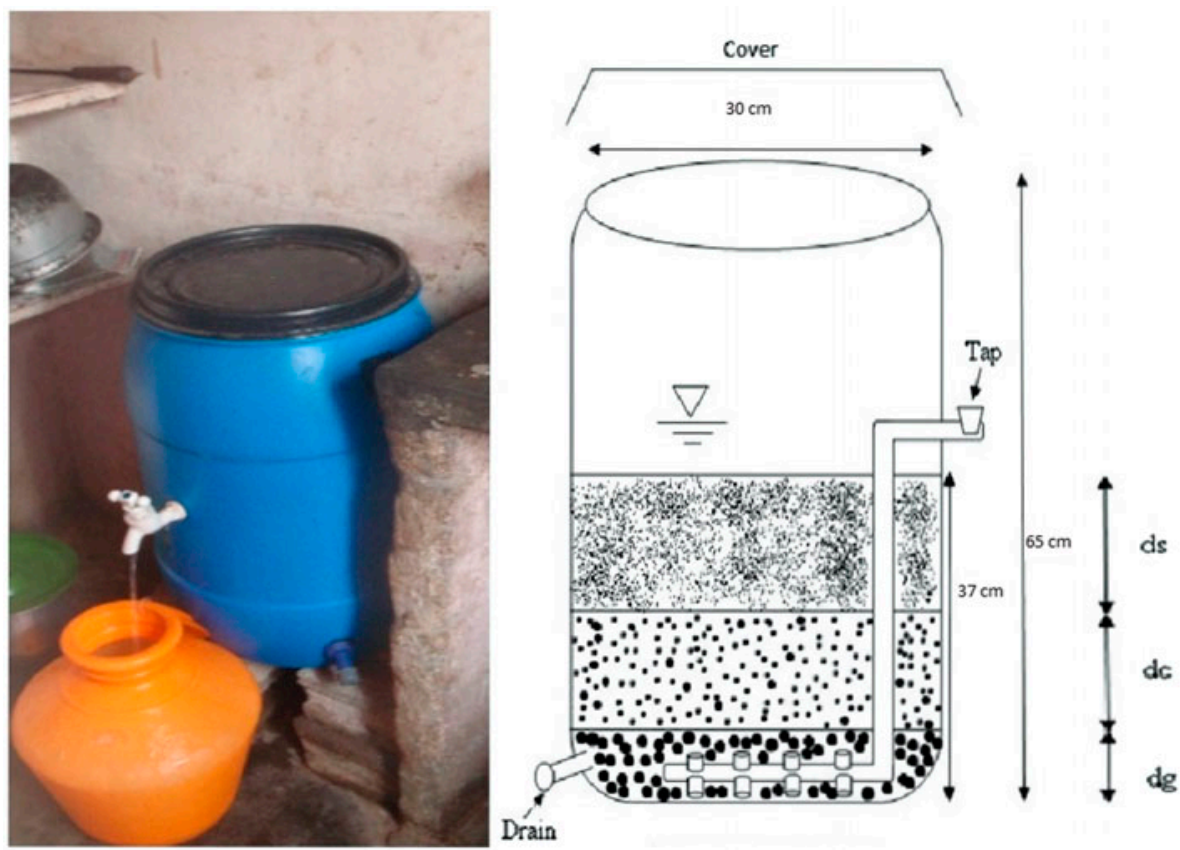

Figure 1. The Safe Water Treatment device operating inside a participant's home (left), and a cross-sectional diagram of the filter technology (right).

Note: Depth of sand $(\mathrm{ds})=15 \mathrm{~cm}$; depth of charcoal $(\mathrm{dc})=15 \mathrm{~cm}$; and depth of gravel $(\mathrm{dg})$ $=7 \mathrm{~cm}$. 
home, as well as a cross-sectional diagram revealing the filter's construction. A $65 \mathrm{~L}$ high-density polyethylene bucket was designed with a PVC pipe manifold to collect water from within the gravel bed and convey it via hydraulic pressure to a tap on the filter's side. It was experimentally determined that one tablet $(35 \mathrm{mg})$ of NaDCC was appropriate for disinfecting $20 \mathrm{~L}$ of filtered water, equal to the volume of the provided storage vessel. To prevent recontamination by human and environmental factors, the storage vessel was constructed with a narrow opening, a lid and a spigot that can be operated by the user. Local leaders and community members worked jointly with researchers during the development of the SWT in an effort to improve community health, disrupt the transmission of waterborne pathogens and ultimately to design a technology that incorporates cultural nuances (MacDonald et al. 2013).

\section{Study population and recruitment of households}

MBN is a peri-urban resettlement colony located on the border of Chennai's municipal limits. MBN relies on a highly polluted surface water source for drinking water. The water is drawn from Narayanapuram Lake, which incidentally receives surface run-off from the streets of neighbouring communities during precipitation events, thus accumulating solid waste as well as human and animal excreta. The water is then pumped, typically untreated, from an adjoining infiltration well to community standpipes where it is collected and used for bathing, food preparation and direct consumption.

A community-level census revealed 180 households that used standpipe water as their primary drinking water source, and therefore met the study inclusion criteria. Of these, 124 households agreed to participate and were randomly assigned to one of two groups: an intervention group receiving the newly designed SWT, and a control group receiving no intervention. All households were monitored for 12 months post baseline, providing monthly water samples and responding to surveys on water treatment, storage and serving practices. All research instruments and methods were approved by the Research Ethics Board at the University of Guelph, Canada, and informed consent was obtained from all participating households prior to data collection.

\section{Sample collection and analysis}

Both treated and untreated water samples were collected from intervention households in sterile autoclaved $250 \mathrm{ml}$ collection bottles and stored on ice between 2 and $8{ }^{\circ} \mathrm{C}$ according to Standard Methods (Rice et al. 2012). Control households were also asked to provide a $250 \mathrm{ml}$ sample of household drinking water. All samples reached the Water Quality Laboratory at the Indian Institute of Technology, Madras, within $8 \mathrm{~h}$ of collection and were immediately analysed for total coliforms, E. coli, turbidity and total residual chlorine (TRC). Turbidity was measured in nephelometric turbidity units (NTU) with a Eutech Instruments TB1000 Cyberscan WL Turbidimeter (Thermo Fisher Scientific, Navi Mumbai, India). TRC was measured using the neutral ortho-toluidine method; the Indian Standard method for determining residual chlorine in water and wastewater (IS 1986). Upon providing samples, households were asked how long it had been since the water was treated. In order to increase the authority of the data-set, their responses (originally four categories) were collapsed to form a binary variable, time since treatment (TST), which identified samples as having been treated either $\leq 6 \mathrm{~h}$ ago, or $>6 \mathrm{~h}$ ago. TST was used in our analysis to stratify the water quality data. 
The standard membrane filtration method was used to enumerate total coliform and E. coli bacteria, as described in Standard Methods for the Examination of Water and Wastewater, 22nd Edition (Rice et al. 2012). Using a vacuum respirator, samples were filtered through a sterile $0.45 \mu \mathrm{m}$ cellulose nitrate membrane, which was then transferred, using sterile forceps, onto pre-dried differential HiCrome Coliform agar medium with sodium lauryl sulphate (used for simultaneous detection of coliforms and E. coli). Samples were incubated upside down for $18-24 \mathrm{~h}$ at $37^{\circ} \mathrm{C}$, after which time pink and blue colonies were counted as coliforms, and blue colonies were counted as E. coli. Average counts of colony-forming units (CFU) per $100 \mathrm{ml}$ of sample water were generated for both total coliform and E. coli bacteria using standard methods (Rice et al. 2012). Log reductions values (LRVs) of total coliforms and E. coli bacteria were calculated as $\log _{10}$ influent water concentration minus $\log _{10}$ filtered water concentration.

The effects of seasonal rainfall and temperature on bacterial concentrations and removal effectiveness were examined using stratified analysis. Rainfall (mean $\mathrm{mm} / \mathrm{mo}$ ) was compared with mean bacterial concentrations for each month. The efficacy of the SWT during the monsoon and dry (or non-monsoon) seasons was calculated by classifying August, September, October and November as monsoon months $(>200 \mathrm{~mm} / \mathrm{mo}$ ), and the remainder as non-monsoon months $(<200 \mathrm{~mm} / \mathrm{mo})$. Independent sample $t$-tests were used to compare the bacterial concentrations of treated and untreated water samples between monsoon and non-monsoon months. Random intercepts linear regressions were performed to determine the predictive capacity of rainfall and temperature on bacterial LRVs, as well as the bacterial concentrations of treated and untreated water samples. Analysis of variance was used to explore statistical differences in bacterial concentrations among water samples. All data from independent replicate trials were pooled by month and analysed using Statistical Analysis Software (the SAS system for Windows, version 7, SAS Institute, Cary, NC), at a significance level of $\alpha=0.05$. Before analysing the data, bacterial concentrations were log-transformed to satisfy the assumption of normality; all other test assumptions, such as linearity, independence and homeoscedasticity, were satisfied by visual inspection of diagnostic plots of residuals.

\section{Results and discussion}

\section{Turbidity}

The turbidity levels of untreated household water samples were identified as low during both the monsoon $(M=1.76, \mathrm{SD}=2.55)$ and non-monsoon $(M=1.38, \mathrm{SD}=1.04)$ months. A similar trend was observed in treated samples during the monsoon $(M=1.33, \mathrm{SD}=1.88)$ and non-monsoon $(M=1.63, \mathrm{SD}=2.57)$ months. Marginal reductions in household drinking water turbidity were not found to be significant $(t=1.14, p=0.256)$ following treatment with the SWT. Also, independent $t$-tests confirmed turbidity to be independent of seasonal variability in both untreated $(t=1.27$, $p=0.206)$ and treated $(t=-0.79, p=0.430)$ household samples.

\section{Bacteriological treatment effectiveness}

All households enrolled in the study used standpipe-provided water sourced from Narayanapuram Lake as their primary drinking water source. However, the proportion of households using standpipe water fluctuated according to its seasonal availability. Household surveys indicate that the intervention group relied on standpipe water $98.5 \%$ 
(95\% CI: 98.2-98.8\%) of the time during the monsoon season, and only $69.5 \%$ (95\% CI: $66.3-72.7 \%$ ) of the time during the non-monsoon season when water is most scarce (i.e. households were forced to identify additional and less desirable water sources).

The mean annual concentrations of total coliform bacteria in control, intervention untreated and intervention treated water samples were 14,727 cfu/100 ml (95\% CI: $12,809-16,645 \mathrm{cfu} / 100 \mathrm{ml}), \quad 14,989 \mathrm{cfu} / 100 \mathrm{ml}$ (95\% CI: $12,744-17,234 \mathrm{cfu} / 100 \mathrm{ml})$ and $718 \mathrm{cfu} / 100 \mathrm{ml}(95 \% \mathrm{CI}: 568-868 \mathrm{cfu} / 100 \mathrm{ml})$, respectively. Independent sample $t$-tests confirmed significant differences in log-transformed total coliform concentrations between control $(M=3.94, \mathrm{SD}=0.56)$ and intervention treated $(M=2.38, \mathrm{SD}=0.84)$ water samples $(t=-26.01, p<0.0001)$, while dependent sample $t$-tests confirmed a significant difference between intervention untreated $(M=3.86, \mathrm{SD}=0.62)$ and intervention treated samples $(t=21.94, p<0.0001)$. The results for $E$. coli were analogous with those for total coliforms, just at lower concentrations, with significant differences between control $(M=3.43, \mathrm{SD}=0.63)$ and intervention treated $(M=1.80, \mathrm{SD}=0.98)$

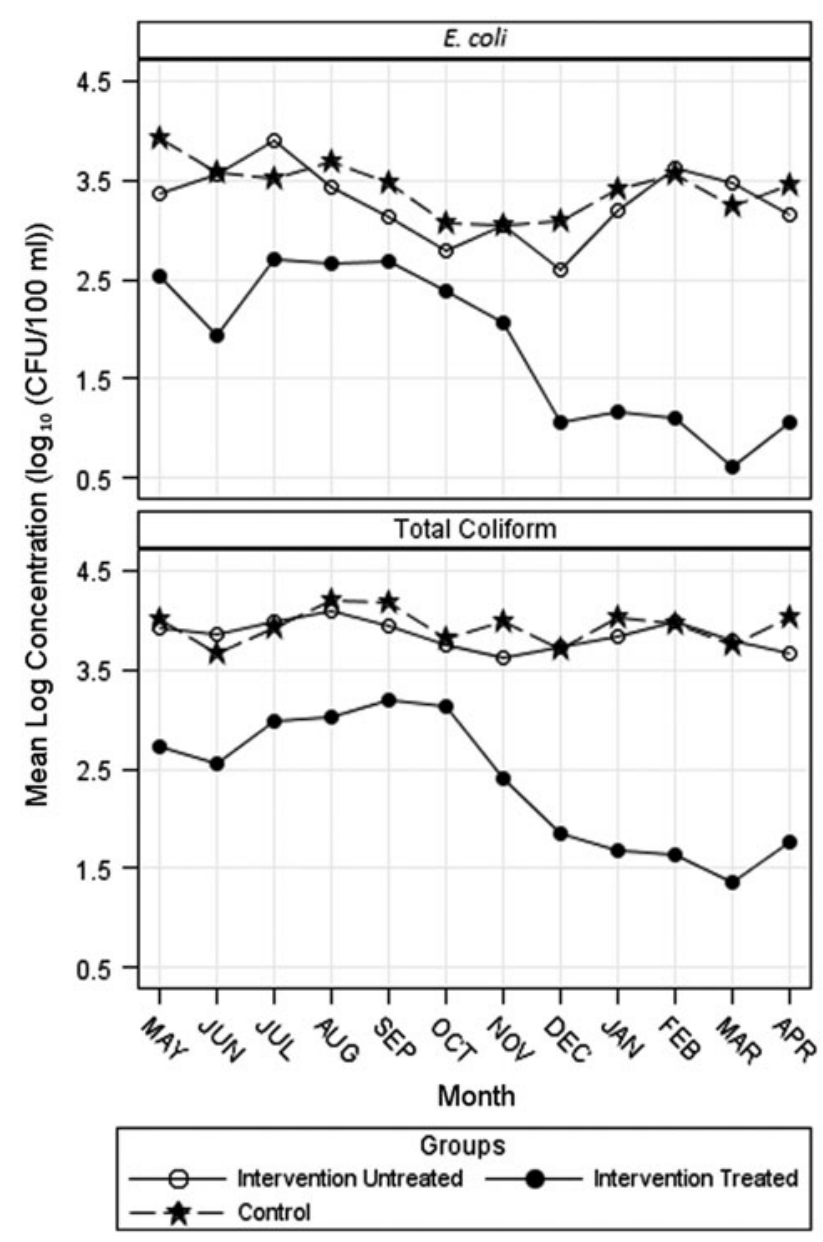

Figure 2. Average log concentrations of E. coli (upper) and total coliform (lower) bacteria for control $(\boldsymbol{\star})$, intervention treated $(\circlearrowleft)$ and intervention untreated $(O)$ household water samples. 
water samples $(t=-14.71, p<0.0001)$ as well as intervention untreated $(M=3.30$, $\mathrm{SD}=0.69)$ and intervention treated $(M=1.80, \mathrm{SD}=0.98)$ samples $(t=13.41$, $p<0.0001)$. Figure 2 presents average $\log$ concentrations of total coliform and E. coli bacteria for each of the 12 months of data collection.

In order to analyse in-field treatment effectiveness, LRVs were calculated by subtracting the log concentrations of bacteria in treated water samples from the log concentrations of bacteria in untreated samples. Average LRVs across all months of study were 1.67 (95 \% CI: 1.50-1.85) for total coliforms and 1.51 (95\% CI: 1.30-1.73) for E. coli. Despite variation in treated water quality, the SWT greatly reduced the concentrations of microbiological contaminants.

\section{Impact of seasonal variability on bacterial indicators}

Chennai's climate is driven by the decadal El Niño cycle and the Indian Ocean oscillation, which influences the Ocean's surface temperature dynamics (Kripalani and Kumar 2004). The temperature fluctuates between 17 and $43{ }^{\circ} \mathrm{C}$, with humidity hovering between 70 and $90 \%$. With two monsoon seasons, the drier southwest monsoon arriving in late June and the relatively wet northeast monsoon arriving in late October, Chennai receives an average annual rainfall of $1391.5 \mathrm{~mm}$ (Government of India Meteorological Department 2012). In the study area, this seasonal variability in rainfall greatly impacts the ephemeral nature of the community water source. However, linear regressions revealed that temperature does not have a significant impact on treatment efficacy of the SWT, by measure of LRVs for total coliform $(p=0.842)$ and $E$. coli $(p=0.769)$. In Figure 3(A), monthly rainfall is plotted according to concentrations of total coliform and E. coli bacteria identified in untreated household water samples. All of the samples collected in January were from sources other than Narayanapuram Lake, and were therefore excluded from our analysis. For this reason, there are no concentrations provided for January in Figure 3. No significant relationship was established in untreated samples between bacterial concentrations and seasonal rainfall. Furthermore, there was no statistically significant difference in untreated total coliform or E. coli concentrations between monsoon and non-monsoon months. However, rainfall was found to be positively correlated with total coliform $(R=0.448, p<0.0001)$ and $E$. coli $(R=0.473, p<0.0001)$ concentrations in treated water samples. These findings are contrary to those reported by Sood et al. (2008), who found a positive correlation between precipitation and concentrations of faecal and total coliforms in the Ganga River. The data also diverge from Hatha et al. (2004), who reported increases in faecal coliform concentrations in the Cochin estuary during the monsoon months, when heavy rains exacerbated the magnitude of waste discharged into the system. In this present study, the data suggest that rainfall may have increased the total volume of Narayanapuram Lake, thereby diluting bacterial concentrations in untreated household water. This hypothesis is reinforced by relatively lower concentrations of indicator bacteria in untreated samples from October through December, either during or immediately following months with heavy rainfall (Figure 3). Similarly, diminishing lake water levels observed during the non-monsoon season may concentrate bacteria by restricting them to a smaller volume of water.

Bacterial densities were generally higher in treated household water samples during the monsoon months (Figure 3(B)). Statistically significant differences in total coliform densities are apparent between monsoon $(M=3.02, \mathrm{SD}=0.55)$ and non-monsoon $(M=2.17, \mathrm{SD}=0.82)$ months, with higher concentrations of total coliforms observed in 

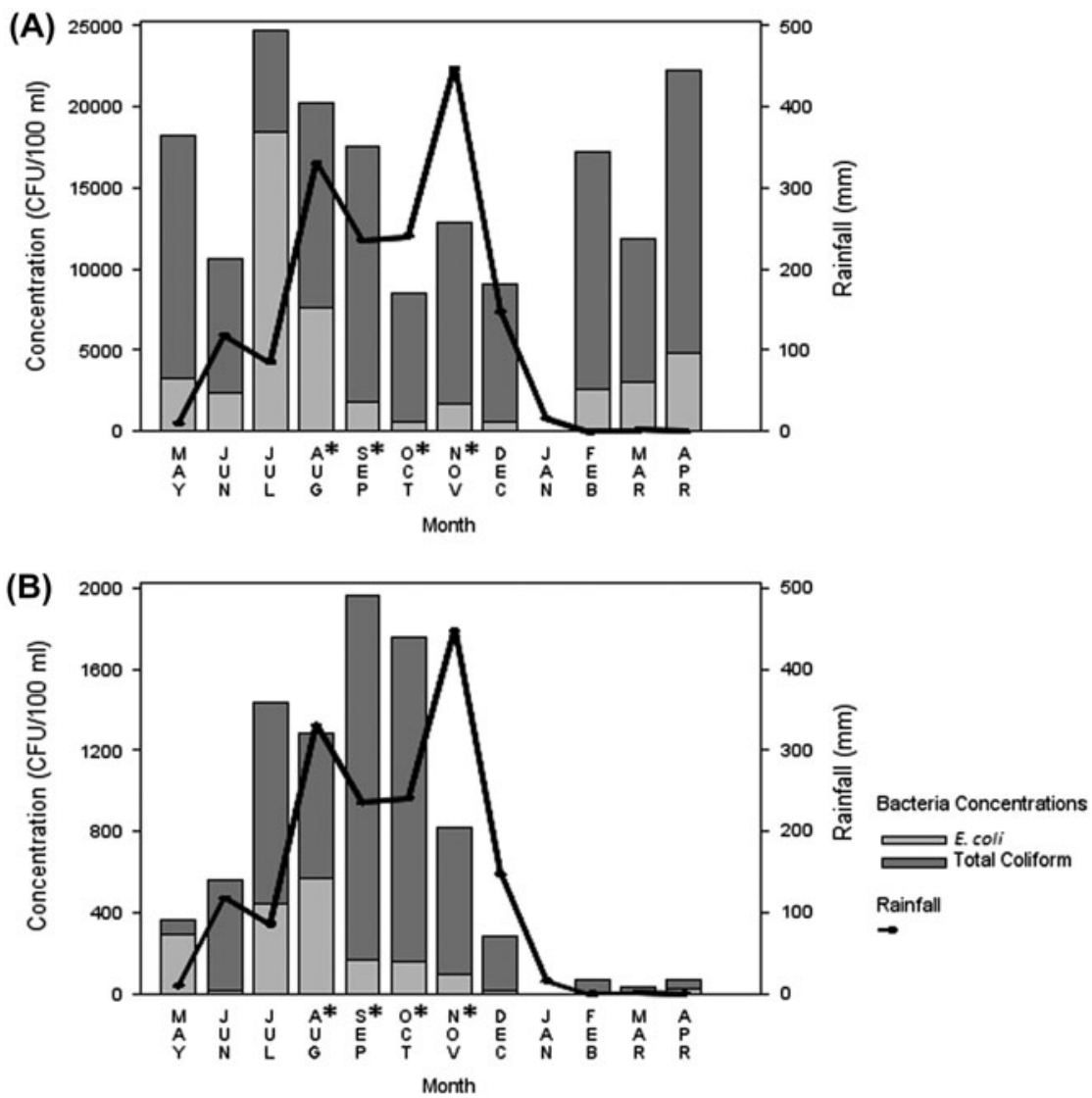

Figure 3. Bacterial concentrations represented by vertical bars in both untreated (A) and treated (B) intervention household water samples with a solid black line to indicate seasonal rainfall. Notes: An asterisk $(*)$ is used to identify each of the four monsoon months as classified in this study. Concentration data are not presented for January, as none of the samples collected this month were from Narayanapuram Lake.

treated water samples during the monsoon season $(t=7.99, p<0.0001)$. E. coli concentrations in treated household water samples were also significantly greater during the monsoon $(M=2.54, \mathrm{SD}=0.53)$ than the non-monsoon $(M=1.55, \mathrm{SD}=1.04)$ season $(t=5.62, p<0.0001)$. These findings were corroborated with simple linear regression modelling, which demonstrated an increase in log coliform concentration of treated water by $0.0032 \log _{10}(\mathrm{cfu} / 100 \mathrm{ml})(p<0.0001)$ for every millimetre of rainfall. Similarly, log concentrations of $E$. coli in treated household water samples were demonstrated to increase by $0.0034 \log _{10}(\mathrm{cfu} / 100 \mathrm{ml})(p<0.0001)$. Linear regressions were used to analyse the effect of rainfall on six dependent variables, specifically bacteriological water-quality parameters. In general, rainfall was associated with significant increases in bacterial concentrations in treated water samples, and reduced removal effectiveness of the SWT. The results of these models are presented in Table 1.

Unexpectedly, treatment effectiveness of the SWT decreased under the conditions presented by heavy rainfall. LRVs for both total coliforms and E. coli were lowest during the monsoon season. It is possible that a gross concentration change in bacteria 
Table 1. The effect of rainfall on bacterial concentrations and SWT treatment effectiveness, results of univariate simple linear regressions.

\begin{tabular}{lrcr}
\hline Response variable & Estimate & SE (Estimate) & $p$ value \\
\hline Log-untreated TC & 0.0002 & 0.0003 & 0.6000 \\
Log-untreated E. coli & -0.0006 & 0.0004 & 0.1514 \\
Log-treated TC & 0.0032 & 0.0004 & $<0.0001$ \\
Log-treated E. coli & 0.0034 & 0.0006 & $<0.0001$ \\
LRV for TC & -0.0039 & 0.0006 & $<0.0001$ \\
LRV for E. coli & -0.0016 & 0.0007 & 0.0131 \\
\hline
\end{tabular}

Note: SWT: Safe Water Technology.

*TC: total coliform

${ }^{+} \mathrm{LRV}$ : $\log$ reduction value.

accompanies the change in seasons. Monthly averages of total coliform LRVs were inversely related to seasonal rainfall $(R=-0.764, p<0.0001)$. E. coli LRVs were also dependent on seasonal rainfall $(R=-0.501, p<0.0001)$. This finding is somewhat counterintuitive: with an increase in rainfall and lower bacterial densities, water treatment efficacy of the SWT was adversely affected. It is possible that with lower concentrations of bacteria entering the SWT, small agglomerations of bacteria were able to be transported through the filter media. If this was the case, only perfectly compliant households (i.e. those that consistently dosed the filtered water with $\mathrm{NaDCC}$ tablets and allowed sufficient time for disinfection) would have remained unaffected by this apparent reduction in filtration efficacy.

\section{Chemical disinfection}

Only $30.1 \%$ of treated water samples exhibited a detectable chlorine residual, suggesting that the majority of households relied exclusively on filtration to treat their drinking water. Perhaps reluctance to disinfect the filtered water with NaDCC tablets may have arisen from a concomitant change in water taste and odour, as has been indicated in previous studies (Reller et al. 2003; Crump et al. 2004). The difference in bacterial concentrations between samples with and without TRC is presented in Figure 4. The comparison of total coliform concentrations between treated water samples with $(M=1.70, \mathrm{SD}=0.79)$ and without $(M=2.42, \mathrm{SD}=0.86)$ a chlorine residual during the non-monsoon months revealed significantly lower concentrations in samples with detectable TRC $(t=2.85, p=0.0058)$. Alternatively, the same comparisons performed on data collected during the monsoon season revealed no difference. This surfaces two plausible explanations. One, the inactivation of waterborne bacteria may have been incomplete if the chlorine demand exceeded the dosage and was consumed by alternative constituents, such as organic matter. Two, the transition between seasons triggered adaptive behavioural changes in the way households treated their drinking water and/or managed water produced by the SWT.

Seasonal differences in physicochemical parameters such as $\mathrm{pH}$, turbidity and organic content were not found to be significant and are therefore unlikely to have affected the efficacy of chemical disinfection. The $\mathrm{pH}$ of untreated standpipe water ranged from 6.5 to 9.6 , with a mean value of 7.98. The difference in $\mathrm{pH}$ between seasons approached significance $(t=1.52, p=0.129)$, but was unlikely to impact bacteriological removal effectiveness. Turbidity of untreated water was generally low, ranging from 


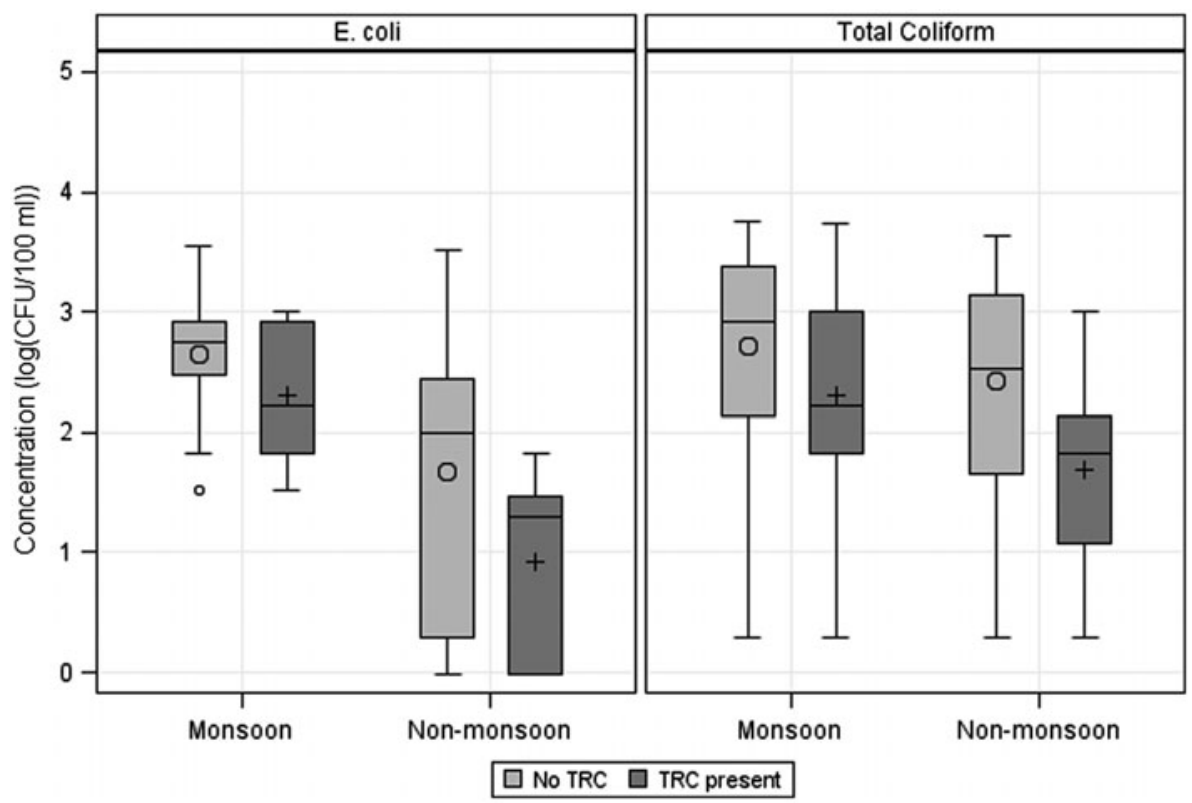

Figure 4. Log concentrations of indicator bacteria in treated water samples with and without residual chlorine during both the monsoon and non-monsoon seasons.

Notes: The bottom and top edges of the box indicate the intra-quartile range (IQR); the marker inside the box indicates the mean value; the line inside the box indicates the median value; and the whiskers indicate the range of values not considered to be outliers (a distance $\leq 1.5^{*} \mathrm{IQR}$ ).

0.04 to $16.0 \mathrm{NTU}$, with a mean of $1.53 \mathrm{NTU}$, and was not found to differ between seasons $(t=1.27, p=0.206)$. It is suspected that the actions of the infiltration well significantly reduced water turbidity, which was again reduced with the settling of suspended solids during the storage of water in the home. Organic content, as indicated by chemical oxygen demand (COD), ranged from 0 to $73.60 \mathrm{mg} / \mathrm{L}$ in untreated samples, with a mean of $20.44 \mathrm{mg} / \mathrm{L}$. No significant difference was observed in the COD of untreated water samples between seasons $(t=-0.53, p=0.595)$.

\section{Time since treatment}

The degradation of bacteriological drinking water quality is linked to extended household storage times (Sobsey 2002; Wright et al. 2004). Brick et al. (2004) cited an increase in drinking water contamination in $67 \%$ of study households in Vellore, India, after storage in the home. Similarly, Juran and MacDonald (2014) demonstrated the presence of $E$. coli in $58 \%$ of stored household water samples retrieved from bacteriologically safe sources in Nagapattinam and Karaikal, India. Dunne et al. (2001) found that the frequency of contamination increased with longer storage times and lower levels of free residual chlorine. Finally, Lantagne and Clasen (2011) posited that time since treatment is correlated with bacteriological contamination, especially in households using chlorine to disinfect their drinking water. Using TST to stratify water-quality data, we found that treated water samples collected within $6 \mathrm{~h}$ of treatment time had significantly lower concentrations of total coliforms $(M=1.76, \mathrm{SD}=0.73)$ than samples 


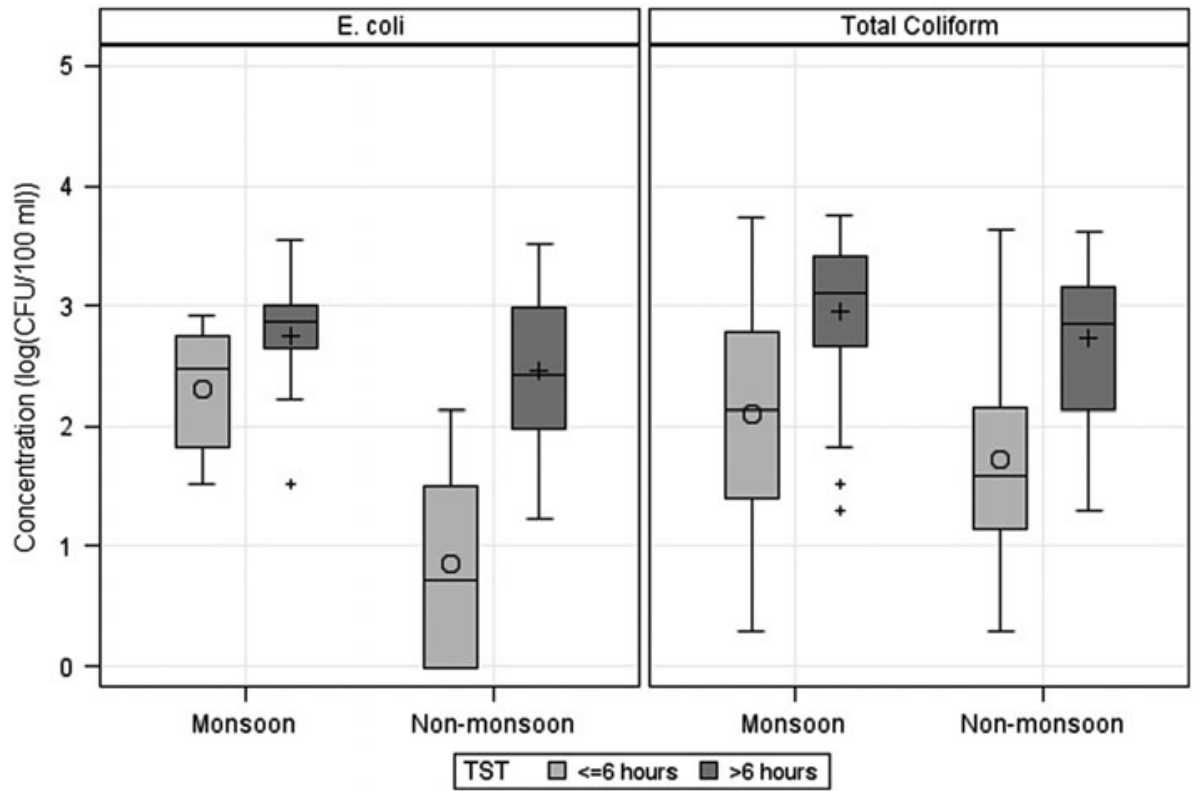

Figure 5. Log concentrations of indicator bacteria in treated water samples during the monsoon and non-monsoon seasons according to time since treatment (TST).

Notes: The bottom and top edges of the box indicate the intra-quartile range (IQR); the marker inside the box indicates the mean value; the line inside the box indicates the median value; and the whiskers indicate the range of values not considered to be outliers (a distance $\leq 1.5^{*} \mathrm{IQR}$ ).

collected $>6 \mathrm{~h}$ after treatment $(M=2.69, \mathrm{SD}=0.62)$ during non-monsoon $(t=-6.81$, $p<0.0001)$ months. Similar results were observed between samples collected within $6 \mathrm{~h}$ of treatment time $(M=2.80, \mathrm{SD}=0.58)$ and those collected $>6 \mathrm{~h}$ after treatment $(M=3.13, \mathrm{SD}=0.50)$ during monsoon $(t=-2.33, p=0.0233)$ months. Similar findings were identified for $E$. coli during both the monsoon $(t=-2.62, p=.0143)$ and non-monsoon $(t=-7.83, p<0.0001)$ months. These findings are presented in Figure 5.

A two-way unbalanced ANOVA was performed on log-transformed total coliform data to determine the combined impacts of Season, TST and the presence of a chlorine residual ("Disinfection") on the efficacy of water treatment. The interaction of Season and TST was significant $(F=5.27, \mathrm{MSE}=2.17, p=0.023)$, suggesting that the influence of these two variables on total coliform concentration is not additive, but co-dependent. Disinfection was also significant $(F=6.88, \quad \mathrm{MSE}=2.83, p=0.010)$, but independent of both Season and TST. The same model performed on log-transformed $E$. coli data identified a similar interaction effect between Season and TST $(F=9.17$, MSE $=3.79, p=0.004)$, but Disinfection was not significant $(p=0.061)$.

\section{Conclusions}

This study provides evidence of significant changes in bacteriological drinking water quality associated with seasonal rainfall. The monsoon months, from late August to November - a period of increased frequency and magnitude of precipitation - revealed a reduction in the bacteriological removal efficiency of the SWT. We originally hypothesized that the regeneration of Narayanapuram Lake by heavy rainfall had a diluting 
effect on E. coli and total coliform bacteria, thus altering the transport and attachment of bacteria through the SWT filter. The dilution of bacteriological concentrations by heavy rainfall in tropical climates has been demonstrated in other studies (Isobe et al. 2004; Santiago-Rodriguez et al. 2012). However, the influent concentrations of indicator bacteria identified in untreated water samples were not significantly different between seasons. Alternatively, the significant interaction between Season and TST suggests a complex convergence of environmental and sociological factors. The monsoon season was marked by higher concentrations of indicator bacteria in treated water samples, a time of the year when water is more plentiful and households are more likely to store treated drinking water for more than $6 \mathrm{~h}\left(\chi^{2}=13.931, p=0.0002\right)$. At the same time, chemical disinfection with $\mathrm{NaDCC}$ was found to be less effective on water collected and treated during the monsoon season.

Evidence of seasonal dependence on household drinking water storage times has significant implications for PoU water treatment in tropical climates with marked variation in seasonal rainfall patterns (e.g. monsoon rains). Thus, the impacts of biophysical and sociological parameters on seasonal performance variability merits further research. Additionally, where chemical disinfection is deployed to treat drinking water, higher doses may be required during or after heavy rainfall events to protect against postcollection contamination and bacterial regrowth (Ali et al. 2011; Harshfield et al. 2012). Recent evidence suggests that diarrhoeal incidence in developing countries is related to heavy rainfall following dry periods (Carlton et al. 2013). As a proactive measure, PoU water treatment and safe storage can mitigate the effects of seasonal bacterial loading of surface waters and reduce the vulnerability of poor and marginalized communities to fluctuations in water quality. However, further research is needed to investigate the nature of the complex relationship between the environment and behavioural change as it relates to household water quality and PoU treatment effectiveness.

\section{Acknowledgements}

The authors would first like to thank all of the study participants from Mylai Balaji Nagar without whom this research would not have been possible. Sincere thanks are also extended to Manikandan Jayaraman, Faridha Begum, Arun Sambath and Pradeep, for their exceptional work in the field and keen insights into community life.

\section{Disclosure statement}

No potential conflict of interest was reported by the authors.

\section{Funding}

This work was supported by the International Development Research Centre, Ottawa, Canada [grant number 105721].

\section{References}

Albert J, Luoto J, Levine D. 2010. End-user preferences for and performance of competing POU water treatment technologies among the rural poor of Kenya. Environ Sci Technol. 44: $4426-4432$.

Ali SI, MacDonald M, Jincy J, Sampath KA, Vinothini G, Philip L, Hall K, Aronson K. 2011. Efficacy of an appropriate point-of-use water treatment intervention for low-income 
communities in India utilizing Moringa oleifera, sari-cloth filtration and solar UV disinfection. J Water Sanit Hyg Dev. 1:112-123.

Blum D, Feachem RG. 1983. Measuring the impact of water supply and sanitation investments on diarrhoeal diseases: problems of methodology. Int J Epidemiol. 12:357-365.

Boschi-Pinto C, Velebit L, Shibuya K. 2008. Estimating child mortality due to diarrhoea in developing countries. Bull World Health Organ. 86:710-717.

Brick T, Primrose B, Chandrasekhar R, Roy S, Muliyil J, Kang G. 2004. Water contamination in urban South India: household storage practices and their implications for water safety and enteric infections. Int J Hyg Environ Health. 207:473-480.

Burkhardt WI, Calci KR, Watkins WD, Rippey SR, Chirtel SJ. 2000. Inactivation of indicator microorganisms in estuarine waters. Water Res. 34:2207-2214.

Carlton EJ, Eisenberg JNS, Goldstick J, Cevallos W, Trostle J, Levy K. 2013. Heavy rainfall events and diarrhea incidence: the role of social and environmental factors. Am J Epidemiol. 178:4-9.

Clasen T, Schmidt W, Rabie T, Roberts I, Cairncross S. 2007. Interventions to improve water quality for preventing diarrhoea: systematic review and meta-analysis. Brit Med J. 334: $782-785$.

Crump JA, Okoth GO, Slutsker L, Ogaja DO, Keswick BH, Luby SP. 2004. Effect of point-of-use disinfection, flocculation and combined flocculation-disinfection on drinking water quality in western Kenya. J Appl Microbiol. 97:225-231.

Dunne EF, Angoran-Bénié H, Kamelan-Tano A, Sibailly TS, Monga BB, Kouadio L, Roels T, Wiktor S, Lackritz E, Mintz E, Luby S. 2001. Is drinking water in abidjan, Côte d'Ivoire, safe for infant formula? J Acquir Immune Defic Syndr. 28:393-398.

Government of India Meteorological Department. 2012. [Internet]. [cited 2012 Mar 8]. Available from: http://www.imdchennai.gov.in/rdwr.html

Harshfield E, Lantagne D, Turbes A, Null C. 2012. Evaluating the sustained health impact of household chlorination of drinking water in rural Haiti. Am J Trop Med Hyg. 87:786-795.

Hatha AAM, Chandran A, Rahiman KMM. 2004. Prevalence of diarrhegenic serotypes of Escherichia coli in the Cochin estuary, along west coast of India. Indian J Mar Sci. 33: 238-242.

Hunter PR. 2009. Household water treatment in developing countries: comparing different intervention types using meta-regression. Environ Sci Technol. 43:8991-8997.

IS. 1986. Indian standard methods of sampling and test for water and wastewater. Part 26, Chlorine Residual, 3025 (Part 26).

Isobe KO, Tarao M, Chiem NH, Minh LY. 2004. Effect of environmental factors on the relationship between concentrations of coprostanol and fecal indicator bacteria in tropical (Mekong Delta) and temperate (Tokyo) freshwaters. Appl Environ Microbiol. 70:814-821.

Jones RM, Liu L, Dorevitch S. 2013. Hydrometeorological variables predict fecal indicator bacteria densities in freshwater: data-driven methods for variable selection. Environ Monit Assess. 185:2355-2366.

Juran L, MacDonald MC. 2014. An assessment of boiling as a method of household water treatment in South India. J Water Health. 12:791-802.

Kosek M, Bern C, Guerrant RL. 2003. The global burden of diarrhoeal disease, as estimated from studies published between 1992 and 2000. Bull World Health Organ. 81:197-204.

Kripalani RH, Kumar P. 2004. Northeast monsoon rainfall variability over south peninsular India vis-à-vis the Indian Ocean dipole mode. Int J Climatol. 24:1267-1282.

Lantagne D, Clasen T. 2011. Project report: assessing the implementation of selected household water treatment and safe storage (HWTS) methods in emergency settings. London: London School of Hygiene and Tropical Medicine.

Liu L, Johnson HL, Cousens S, Perin J, Scott S, Lawn JE, Rudan I, Campbell H, Cibulskis R, Li M, Mathers C, Black RE. 2012. Global, regional, and national causes of child mortality: an updated systematic analysis for 2010 with time trends since 2000. Lancet. 379:2151-2161.

MacDonald MC, Ali SI, Hall K. 2013. Collaborative innovation for the development of contextually appropriate water treatment technology in a marginalized, low-income South Asian community. Int J Tech Knowl Soc. 8:105-120.

Martin AR, Coombes PJ, Harrison TL, Dunstan RH. 2010. Changes in abundance of heterotrophic and coliform bacteria resident in stored water bodies in relation to incoming bacterial loads following rain events. J Environ Monitor. 12:255-260. 
Reller ME, Mendoza CE, Lopez MB, Alvarez M, Hoekstra RM, Olson CA, Baier KG, Keswick BH, Luby SP. 2003. A randomized controlled trial of household-based flocculant-disinfectant drinking water treatment for diarrhea prevention in rural Guatemala. Trop Med. 69:411-419.

Rice EW, Baird RB, Eaton AD, Clesceri LS, editors. 2012. Standard Methods for the Examination of Water and Wastewater. 22nd ed. Washington (DC): American Public Health Association/ American Water Works Association/Water Environment Federation.

Sahoo KC, Tamhankar AJ, Johansson E, Lundborg CS. 2010. Antibiotic use, resistance development and environmental factors: a qualitative study among healthcare professionals in Orissa. India BMC Pub Health. 10:1-10.

Santiago-Rodriguez TM, Tremblay RL, Toledo-Hernandez C, Gonzalez-Nieves JE, Ryu H, Santo-Domingo JW, Toranzos GA. 2012. Microbial quality of tropical inland waters and effects of rainfall events. Appl Environ Microbiol. 78:5160-5169.

Sharan R, Chhibber S, Attri S, Reed RH. 2010. Inactivation and injury of Escherichia coli in a copper water storage vessel: effects of temperature and $\mathrm{pH}$. Antonie Van Leeuwenhoek. 97:91-97.

Sobsey M. 2012. Managing water in the home: accelerated health gains from improved water supply. Geneva: World Health Organization; p. 1-81.

Sood A, Singh KD, Pandey P, Sharma S. 2008. Assessment of bacterial indicators and physicochemical parameters to investigate pollution status of Gangetic river system of Uttarakhand (India). Ecol Ind. 8:709-717.

Stauber CE, Ortiz GM, Loomis DP, Sobsey MD. 2009. A randomized controlled trial of the concrete biosand filter and its impact on diarrheal disease in Bonao. Dominican Republic Trop Med. 80:286-293.

WHO. 2002. The world health report: reducing risks, promoting healthy life. Geneva: World Health Organization; p. 1-230.

WHO. 2011. Drinking water equity, safety and sustainability. Geneva: World Health Organization.

Wright J, Gundry S, Conroy R. 2004. Household drinking water in developing countries: a systematic review of microbiological contamination between source and point-of-use. Trop Med Int Health. 9:106-117. 


\title{
The impact of rainfall and seasonal variability on the removal of bacteria by a point-of-use drinking water treatment intervention in Chennai, India
}

\author{
Morgan C. MacDonald, Luke Juran, Jincy Jose, Sekar Srinivasan, Syed I. Ali, \\ Kristan J. Aronson \& Kevin Hall
}

To cite this article: Morgan C. MacDonald, Luke Juran, Jincy Jose, Sekar Srinivasan, Syed I. Ali, Kristan J. Aronson \& Kevin Hall (2015): The impact of rainfall and seasonal variability on the removal of bacteria by a point-of-use drinking water treatment intervention in Chennai, India, International Journal of Environmental Health Research, DOI: 10.1080/09603123.2015.1089532

To link to this article: http://dx.doi.org/10.1080/09603123.2015.1089532

Published online: 25 Sep 2015.

\section{Submit your article to this journal $\pi$}

Џ Article views: 15

Q View related articles

View Crossmark data $\asymp$ 